Article

\title{
How Management Factors Influence Weed Communities of Cereals, Their Diversity and Endangered Weed Species in Central Europe
}

\author{
Matthias Schumacher *, Simon Ohnmacht, Ronja Rosenstein and Roland Gerhards \\ Department of Weed Science, Institute of Phytomedicine, University of Hohenheim, 70599 Stuttgart, Germany; \\ Simon_Ohnmacht@uni-hohenheim.de (S.O.); ronja.rosenstein@web.de (R.R.); \\ Roland.Gerhards@uni-hohenheim.de (R.G.) \\ * Correspondence: matthias.schumacher@uni-hohenheim.de; Tel.: +49-711-459-22398
}

Received: 20 October 2018; Accepted: 31 October 2018; Published: 2 November 2018

\begin{abstract}
The loss of weed biodiversity in agricultural fields is a global issue that needs to be counteracted to preserve their supported ecosystem services and food webs. Many short-term efforts are undertaken to conserve weed species, especially already endangered ones, but several years after expiration, eventually result in species-poor communities. Understanding drivers of community composition is key to prevent biodiversity loss. To understand the factors that shape weed communities and influence weed diversity and endangered weed species, we monitored conventional and organic cereal fields in two regions of southwestern Germany. A redundancy analysis was performed on vegetation recordings and data from a farmer survey. Crop species, herbicide use, farming system, nitrogen, and light availability had the strongest impact on weed diversity. The weed communities were dominated by Alopecurus myosuroides, Galium aparine, Viola arvensis, Polygonum convolvulus, and Veronica persica, and were mainly shaped by crop species, tillage, location in the field, and timing of herbicide application. Bromus grossus and Bromus secalinus, two endangered weed species, survived in conventional field margins as a result of the use of herbicides with gaps for Bromus species. Conservation efforts are not restricted to organic farming and should consider the major drivers of weed communities. Precision farming techniques are available to create networks of habitats for endangered and common weed species and subsequently increase agro-biodiversity per se.
\end{abstract}

Keywords: Bromus grossus; Bromus secalinus; rare arable weed species; redundancy analysis (RDA); species conservation; weed community; weed diversity

\section{Introduction}

The Convention on Biological Diversity (CBD) is an international treaty dedicated to the conservation of biological diversity, its sustainable use, and the sharing of genetic resources. So far, 168 countries have signed this treaty, which highlights the global importance of biodiversity [1]. The Global Strategy for Plant Conservation (GSPC) within the CBD aims specifically at stopping the loss of further plant species, conserving their natural habitats, and using plant diversity in a sustainable manner. As plants are the lowest trophic level, they support the whole food chain within an ecosystem. Conservation of plant species thus means also conserving animal species of higher trophic levels $[2,3]$. As large areas within countries are naturally used for food production, the tradeoff between production and conservation becomes a controversial issue [4]. However, agro-ecosystems in particular have suffered from species loss in the last decades [5]. Not only plant species [6], but also insects [7] and larger vertebrate animals such as birds [8], have decreased in population size and species numbers in 
agricultural fields. The reasons for this species decline in agro-ecosystems are manifold; intensification of the production system, excessive use of water, nutrients and chemicals, as well as pollution of the environment [9]. Weeds in particular represent one of the most important biological constraints for crop production as they affect quantity and quality of the harvest product as a result of competition [10]. On the other hand, they are the basis for the whole food chain in the agro-ecosystem and provide a range of important ecosystem services [11]. The decline of weed species in agro-ecosystems is inter alia attributed to high fertilizer inputs, the use of efficient weed control measures like herbicides, improvements in soil tillage, and the increased competitive abilities of crop plants since the middle of the 20 th century [6,12]. Until today, the number of weed species has declined by $64 \%$ [13]. Many of the species became highly endangered or even extinct [6]. A once diverse weed flora is nowadays dominated by those few species that were able to cope with the agricultural intensification process.

Conserving weed species, and endangered ones in particular, not only adds to the conservation of food webs and animals of higher trophic levels [3,12], it further supports beneficial insects that combat major pests [14] and preserves potential genetic resources in the gene pool [15]. Eventually, these species represent cultural assets of former agricultural production systems and have an intrinsic aesthetic value for humans [16]. In order to protect endangered weed species (EWS), a wide spectrum of conservation measures has evolved, from in situ conservation under actual farming to field margin concepts and floral nature reserves [17]. As weeds have co-evolved with the crop plants, they often need specific farming operations to survive; for example, Agrostemma githago propagates with contaminated crop seeds [18]. Therefore, many in situ conservation strategies give monetary compensation to farmers in return for particular management restrictions. These restrictions comprise higher row distances to lower the light competition of the crop, less nitrogen fertilization and abandonment of herbicides, and other non-chemical weed control methods. Moreover, they are in line with special requirements of the endangered species like late stubble tillage to enable species that flower very late to produce seeds or a higher proportion of winter cereals in the crop rotation, because most endangered species germinate in autumn $[19,20]$. The fields should also be ploughed on a regular basis to prevent the spread of competitive grass weeds and perennials [19]. These measures aim to increase the chances of survival and propagation of EWS and ultimately increase their population sizes.

Although conservation measures are used, most of the fields have suffered from the species decline and display a very low diversity of weed species $[6,21]$. Although, not only the species number, but also their respective coverage and genetic diversity, have decreased over the years [6,22], which in the long run leads to lower amounts of seeds in the soil seed bank, and ultimately to the disappearance of species. The resulting modern weed community is impoverished and exhibits only a handful of species that occur almost everywhere throughout Germany. Chenopodium album, Viola arvensis, Polygonum convolvulus, Polygonum aviculare, and Galium aparine are typically among these species [6], as well as Alopecurus myosuroides, which experienced a dramatic increase due to its development of herbicide resistance [23] and higher percentages of winter cereals in the rotation.

Conservation contracts with famers in Germany are normally effective in preserving the occurring endangered species [24], but are also unfortunately subject to time limitations. Fields whose contracts have expired often display weed communities similar to conventionally farmed fields after several years [25]. Additionally, there is only little information about the habitat and management requirements of EWS [26], as well as of common ones. This lack of knowledge diminishes the success of the conservation efforts themselves and leads to further impoverishment of the weed community. Identifying key drivers of weed community composition and EWS is urgently needed to derive effective measures and strategies for successful species conservation.

Within this study, we performed weed vegetation recordings and farmer surveys in two regions of southwestern Germany where EWS were protected during the last decade, but are currently not under conservation contracts. The aim of this work was to detect driving factors of weed community assembly, weed diversity, and particularly of the occurrence of EWS. The resulting knowledge can be used to improve conservation measures for EWS and the enhancement of in-field biodiversity. We thus 
determined the agronomic and environmental factors in cereal crops that (i) shape the present weed community, and identified those factors that positively affect (ii) weed species diversity and (iii) the occurrence of EWS.

\section{Materials and Methods}

\subsection{Experimental Areas and Field Selection}

Vegetation recordings were performed in the regions "Gäu" and "Swabian Alps" in the southwestern part of Germany. The "Gäu" region is located between the Black Forest and the Swabian Alps. Soils in the region can range from sandy clay to heavy clay soils. Muschelkalk (shellbearing limestone) or Unterer Keuper (sandstone or clay) were the parent rocks for these soils. The long-term mean (1960-1990) of temperature is $7.1-8.0^{\circ} \mathrm{C}$ and the mean precipitation is $900-1000 \mathrm{~mm}$. The Swabian Alps originated to a large extent from Jurassic limestone (limestone with clay marl and mudstone) that turned into rendzina soils, Terra fusca, vertic cambisols, or (chromic) luvisols. The long-term mean of temperature on the Swabian Alps is $6.1-7.0^{\circ} \mathrm{C}$ and the precipitation ranges from 1000 to $1200 \mathrm{~mm}$.

In 2017, cereal fields were selected in the Gäu region on the basis of former recordings of Bromus grossus, which is an almost extinct species in Germany, by the regional nature conservation authority (2004-2015). We wanted to determine if this species was still present in the region. Therefore, fields surrounding the formerly confirmed areas of the occurrence of B. grossus were chosen for the recording. We mapped 33 fields, of which 28 were conventionally farmed and 5 were organically farmed. In 2018, we carried out the same search pattern in the Swabian Alps region. The recordings of a private nature conservation organization from 2006 had documented the occurrence of rare weed species such as Bromus secalinus, Neslia paniculata, Legousia hybrid, and Vaccaria hispanica. In total, 33 fields, consisting of 30 conventionally farmed and 3 organically farmed, were mapped.

\subsection{Vegetation Recordings and Farmer Surveys}

The vegetation recordings were performed according to van Elsen [27], who used a $2 \mathrm{~m}$ by $50 \mathrm{~m}$ area along the field margin and a second strip, parallel to the first, in the middle of the field. All occurring plant species were noted according to the extended Braun-Blanquet scale by Wilmanns [28]. The obtained data were afterwards transformed according to Van der Maarel [29].

To be able to relate the recorded weed community or the occurrence of rare arable weed species to farming practices, we performed a farmer survey. The survey retrieved information about crop species, fertilization, soil tillage, and weed control measures. However, not all farmers were willing to or could share all their available information. Therefore, we used only variables that were consistent for all vegetation recordings within a region for the statistical analysis. Additionally, we measured crop height, nitrate $\left(\mathrm{NO}_{3}\right)$ and ammonium $\left(\mathrm{NH}_{4}\right)$ content in the soil, and photosynthetic active radiation (PAR) at soil level between the crop rows, and assessed the soil type. Table 1 shows the obtained variables in each region and their levels.

Table 1. Levels and ranges of categorical and metric variables assessed by a farmer survey in the Gäu region and the Swabian Alps.

\begin{tabular}{|c|c|c|}
\hline \multirow{2}{*}{ Variable } & Gäu Region & Swabian Alps \\
\hline & Levels & Levels \\
\hline Location in the field & Field margin; field middle & Field margin; field middle \\
\hline Farming system & Organic; conventional & Organic; conventional \\
\hline Crop species & $\begin{array}{l}\text { winter mix }{ }^{1} \text {; spelt; winter barley; } \\
\text { winter wheat; triticale }\end{array}$ & $\begin{array}{c}\text { Oat; rye; spring barley; triticale; winter } \\
\text { barley; winter wheat }\end{array}$ \\
\hline $\begin{array}{c}\text { Photosynthetic active radiation (PAR) at soil } \\
\text { level (\%) }\end{array}$ & $1.3-18.4$ & $2.8-70.0$ \\
\hline Crop cover $(\%)$ & $55.0-95.0$ & $30.0-97.0$ \\
\hline Nitrate in the soil in June $\left(\mathrm{NO}_{3}\right)\left(\mathrm{kg} \mathrm{ha}^{-1}\right)$ & $1.7-115.9$ & - \\
\hline
\end{tabular}


Table 1. Cont.

\begin{tabular}{|c|c|c|}
\hline \multirow{2}{*}{ Variable } & Gäu Region & Swabian Alps \\
\hline & Levels & Levels \\
\hline $\mathrm{NH}_{4}$ in the soil in June $\left(\mathrm{kg} \mathrm{ha}^{-1}\right)$ & $0.0-17.5$ & - \\
\hline Soil type & $\mathrm{lT}, \mathrm{tL}, \mathrm{t}^{\prime} \mathrm{L}, \mathrm{uL}, \mathrm{tU}^{2}$ & - \\
\hline Timing of herbicide application & $\begin{array}{l}\text { Spring appl.; autumn appl.; spring + } \\
\text { autumn appl. } 3\end{array}$ & $\begin{array}{c}\text { Spring appl.; autumn appl.; spring + } \\
\text { autumn appl. }\end{array}$ \\
\hline Total nitrogen fertilization $\left(\mathrm{kg} \mathrm{ha}^{-1}\right)$ & $0.0-271.5$ & $44.0-110.0$ \\
\hline Crop row distance $(\mathrm{cm})$ & $12.0-17.0$ & $12.2-15.0$ \\
\hline Seeding density $\left(\mathrm{kg} \mathrm{ha}^{-1}\right)$ & $140.0-260.0$ & $100.0-250.0$ \\
\hline Number of applied herbicides & $0-3$ & - \\
\hline Number of tillage operations & $2-4$ & $2-4$ \\
\hline Tillage & Plough; reduced tillage & Plough; reduced tillage \\
\hline Crop height $(\mathrm{cm})$ & $51-153$ & $45-150$ \\
\hline Field size (ha) & - & $0.15-5.00$ \\
\hline Nitrogen fertilization & - & Mineral; organic; mineral + organic \\
\hline
\end{tabular}

${ }^{1}$ winter mix consists of triticale, rye, winter oat, winter barley, and winter pea; ${ }^{2} \mathrm{lT}=$ loamy clay, $\mathrm{tL}=\mathrm{clayey}$ loam, $\mathrm{t}^{\prime} \mathrm{L}=$ weakly clayey loam, $\mathrm{uL}=$ silty loam, $\mathrm{tU}=$ loamy silt; ${ }^{3}$ appl. = application.

\subsection{Data Analysis}

Statistical analysis was performed with the software R (version 3.4.3, R Foundation for Statistical Computing, Vienna, Austria). Species numbers were analyzed with the standard analysis of variance (ANOVA) and means compared with a Tukey-HSD-test $(p \leq 0.05)$.

To detect influences of farming or environmental variables on the weed species composition, we performed a redundancy analysis (RDA). Species were transformed by the Hellinger approach [30] prior to analysis. The final model with environmental and farming variables was selected by a stepwise forward selection with a threshold of $p \leq 0.05$. The generalized variance inflation factor (GVIF) for the variables were between 1.1 and 6.7 most of the time, except for two levels of the variable "crop", which were between 10 and 20. Values of GVIF above 20 indicate collinearity between variables [31]. To detect the effects of single explanatory variables we calculated gross and net effects of each variable according to Lososova et al. [32]. The gross effect represents the explained variation of the target variable under a univariate RDA, while the net effect represents the explained variation under a partial RDA (pRDA) with the target variable as explanatory variable and the other variables of the model as covariables. The fit for the models of net effect was tested afterwards using a permutation test with 999 permutations of the constrained axis for each model.

\section{Results}

\subsection{Weed Species Diversity}

In total, 140 different weed species were found in the Gäu region and 93 weed species in the Swabian Alps. The average number of weed species in each recorded plot typically ranged between 10 and 30. We found six variables that significantly affected the weed species number in the Gäu region. These variables were location in the field, crop species, number of herbicide applications, farming system, total nitrogen fertilization, and the amount of PAR at soil level (Figure 1). Meanwhile, there were only three variables in the Swabian Alps that affected weed diversity significantly, namely, location in the field, number of different crops in the crop rotation, and farming system (Figure 2).

Species numbers in the Gäu region and the Swabian Alps were higher in organic (28.1 and 27.3, respectively) compared with conventional farming (12.9 and 11.2, respectively), and were always higher at the field margin (20.8 and 16.2, respectively) in comparison with the middle of the field (9.5 and 10.0, respectively). In the Gäu region, a prominent effect of the different crop species was present, while in the Swabian Alps, the number of crops in the crop rotation significantly influenced the weed species numbers. Moreover, in the Gäu region, total nitrogen fertilization was negatively correlated with weed species diversity, while the amount of PAR was positively correlated (See Figure 1e,f). A significantly higher number of weed species was present if any herbicide application was omitted 
(28.2 species). However, sprayed plots also showed rather high species numbers (10.1 to 13.4), although not significantly different from each other.

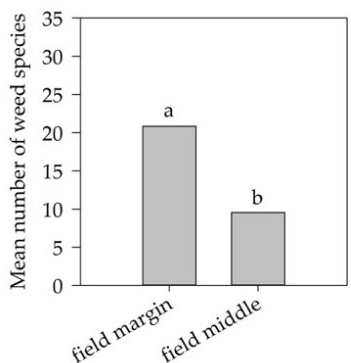

(a)

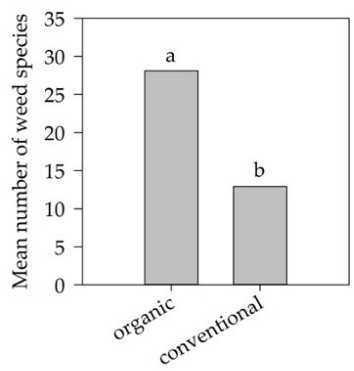

(d)

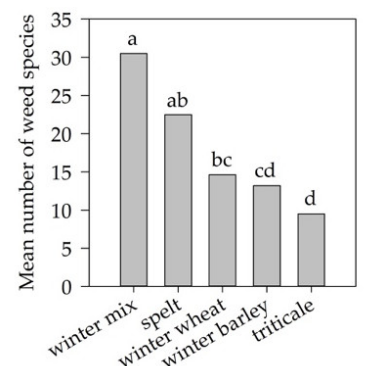

(b)

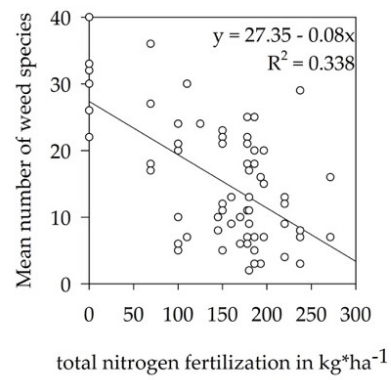

(e)

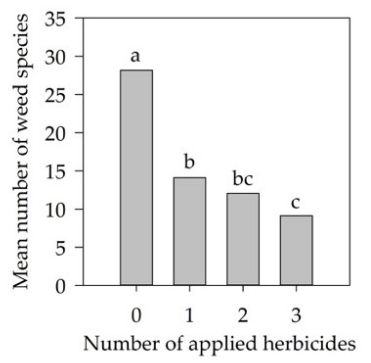

(c)

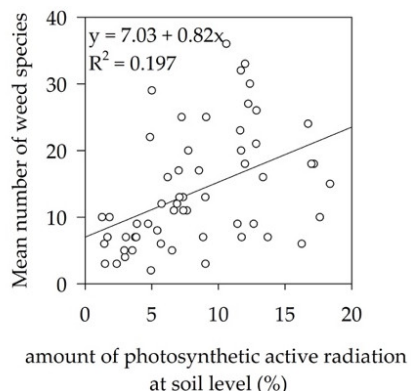

(f)

Figure 1. Factors influencing the mean number of weed species in the Gäu region (a) location in the field; (b) crop species; (c) number of applied herbicides; (d) farming system; (e) total nitrogen fertilization ( $y=27.35-0.08 x ; R^{2}=0.338$ ); and (f) amount of photosynthetic active radiation at soil level $\left(y=7.03+0.82 x ; R^{2}=0.197\right)$. Means with different letters represent significant differences according to the Tukey HSD test $(p \leq 0.05)$.

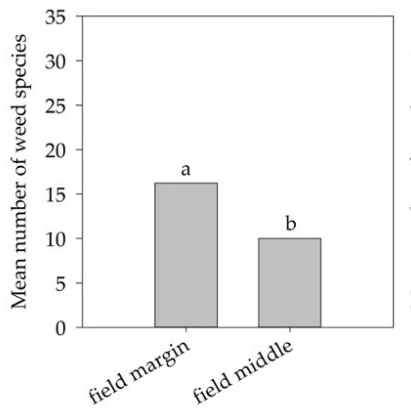

(a)

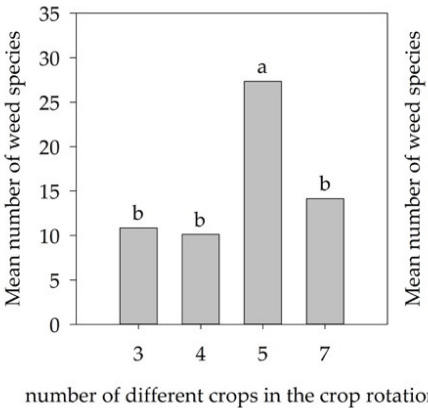

(b)

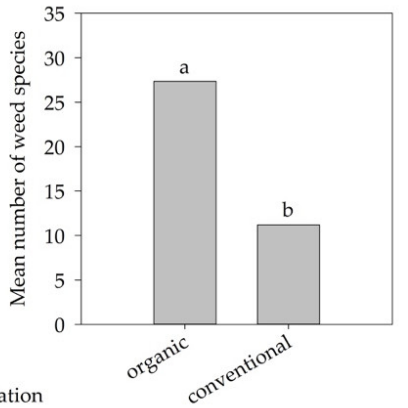

(c)

Figure 2. Factors influencing the mean number of weed species in the Swabian Alps (a) location in the field; (b) number of different crops in the crop rotation; and (c) farming system. Means with different letters represent significant differences according to the Tukey HSD test $(p \leq 0.05)$.

\subsection{Weed Species Community}

The weed species communities in both locations were very similar in terms of weed species occurrence (Figure 3). Alopecurus myosuroides, Galium aparine, Viola arvensis, Polygonum convolvulus, and Veronica persica were the most frequent species and were present in more than $50 \%$ of the recorded plots. These five species were also within the top ten species in regard to mean soil cover at both locations. The weed species coverage was generally lower in the Swabian Alps compared with the Gäu region. The majority of species, 73\% of all species in the Gäu region and 52\% in the Swabian Alps, were not very frequent $(<10 \%$ occurrence). More than $75 \%$ of the weed species also showed a mean soil cover that was below $0.5 \%$ (78\% for the Gäu region and $82 \%$ for the Swabian Alps). 


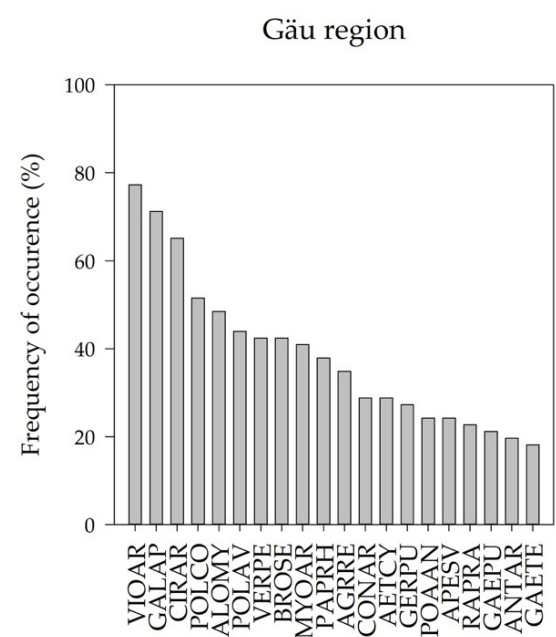

(a)

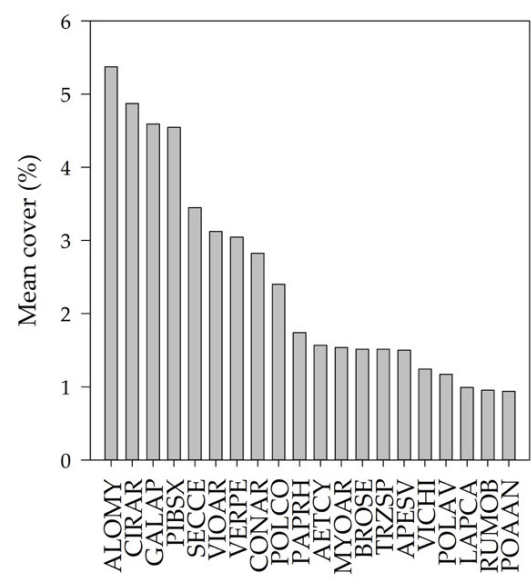

(c)

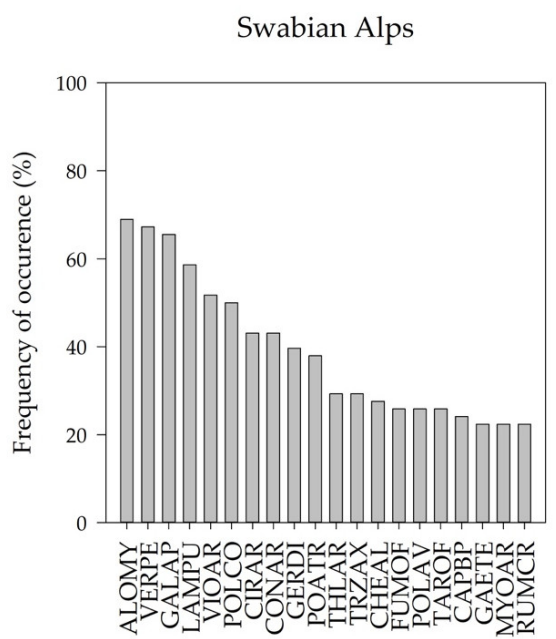

(b)

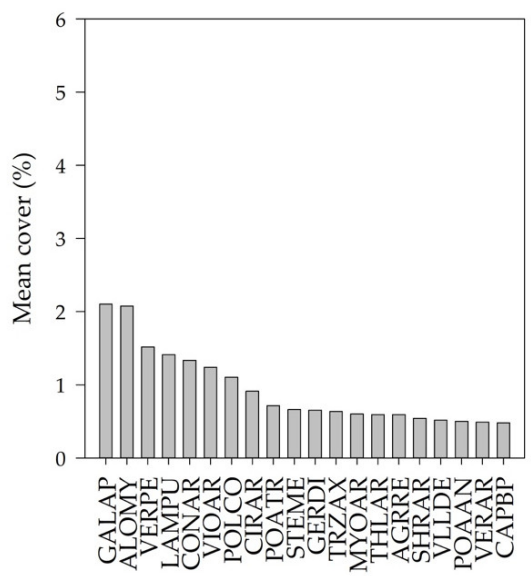

(d)

Figure 3. Values of $(\mathbf{a}, \mathbf{b})$ frequency of occurrence $(\%)$ and $(\mathbf{c}, \mathbf{d})$ mean cover $(\%)$ for those 20 weed species with the highest occurrence or soil cover in the $(\mathbf{a}, \mathbf{c})$ Gäu region or the $(\mathbf{b}, \mathbf{d})$ Swabian Alps. Abbreviation of weed species according to the EPPO (European and Mediterranean Plant Protection Organization) Code.

The stepwise forward selection of the model in the RDA analysis selected six variables for the Gäu region and eight for the Swabian Alps that significantly affected the composition of the weed communities (Table 2). The full model was able to explain more than $40 \%$ of the total variation in the species composition in both locations. The models of both regions share four variables, namely, crop species, tillage, location in the field, and timing of the herbicide application. Of these four variables, crop species and timing of herbicide application were the two variables explaining the biggest part of the species community.

The RDA plots in Figure 4 show the association of the respective weed species in each location to the selected variables from the model. In the Gäu region, the first RDA axis was associated with the number of applied herbicides, the timing of application, and $\mathrm{NH}_{4}$ content in the soil. The second axis was associated with the tillage and the location of records in the field. Polygonum convolvulus and Veronica persica were associated with reduced tillage and winter wheat or triticale, while Bromus secalinus and Bromus grossus, two endangered species, were associated with a low content of ammonia in the soil and combined spring and autumn herbicide applications. Rumex species on the contrary were associated with higher values of ammonia in the soil. The first axis of the RDA in the Swabian Alps was associated with the total nitrogen fertilization of the farmer, whereas the second axis was associated with seeding density, number of tillage operations, crop species, and timing of herbicide 
application. Galium aparine had a higher association with oats and winter barley than any other weed species. Alopecurus myosuroides was present under higher values, while Galium aparine was more abundant at medium values of nitrogen fertilization. Additionally, Alopecurus myosuroides was more frequent if the number of tillage operations was low. Polygonum convolvulus and Veronica persica in the Swabian Alps were also associated with a low number of tillage operations.

Table 2. Explained variation (\%) of the full model, as well as the gross (redundancy analysis (RDA) with single explanatory variable) and net ((partial) RDA with single explanatory variable and additional variables held constant) effects of the explanatory variables on weed species composition and their F-values from the permutation test for the Gäu region and the Swabian Alps.

\begin{tabular}{ccccccc}
\hline \multirow{2}{*}{ Variables } & \multicolumn{3}{c}{ Gäu Region } & \multicolumn{3}{c}{ Swabian Alps } \\
\cline { 2 - 7 } & Gross Effect & Net Effect & F-Value & Gross Effect & Net Effect & F-Value \\
\hline Full model ${ }^{1}$ & 42.54 & & $3.634^{* * *}$ & 46.63 & & $2.185^{* * *}$ \\
Crop species & 21.92 & 12.61 & $2.963^{* * *}$ & 19.05 & 20.83 & $2.276^{* * *}$ \\
Tillage & 7.79 & 5.37 & $5.049^{* * *}$ & 3.39 & 3.31 & $2.174^{* *}$ \\
Number of herbicide applications & 7.13 & 2.60 & $2.441^{* *}$ & - & - & - \\
Location in the field & 2.77 & 2.63 & $2.471^{* * *}$ & 3.20 & 3.20 & $2.101^{* *}$ \\
Herbicide timing & 16.51 & 5.93 & $1.857^{* * *}$ & 11.44 & 7.51 & $2.463^{* * *}$ \\
NH & 4.56 & 2.37 & $2.235^{* *}$ & & & \\
Total N & & & & 4.21 & 4.53 & $2.968^{* * *}$ \\
Farming system & & & & 5.59 & NA & NA \\
Number of tillage operations & & & & 2.11 & 2.76 & $1.812^{* *}$ \\
Seeding density & & & & 2.87 & 2.53 & $1.659^{*}$ \\
\hline
\end{tabular}

${ }^{1}$ Full model selected by stepwise forward selection with an adjusted $R^{2}$ of 0.3083 at the Gäu region and 0.2529 at the Swabian Alps. ${ }^{* * *} p \leq 0.001,{ }^{* *} p \leq 0.01,{ }^{*} p \leq 0.05$, NA $=$ not available).

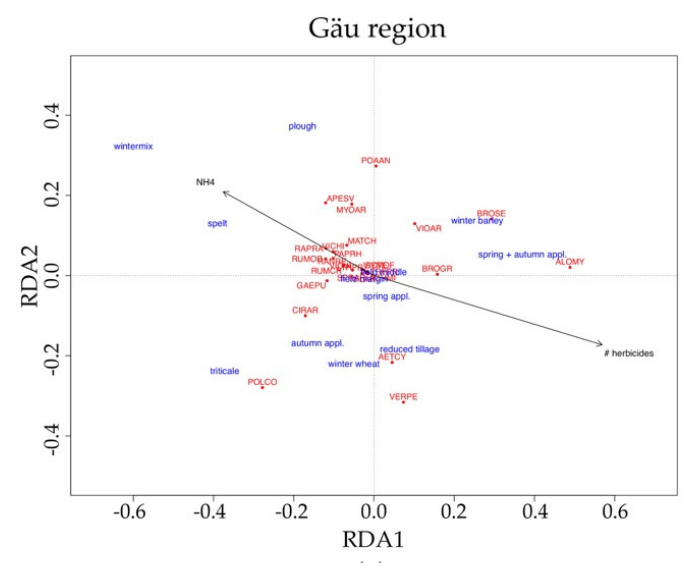

(a)

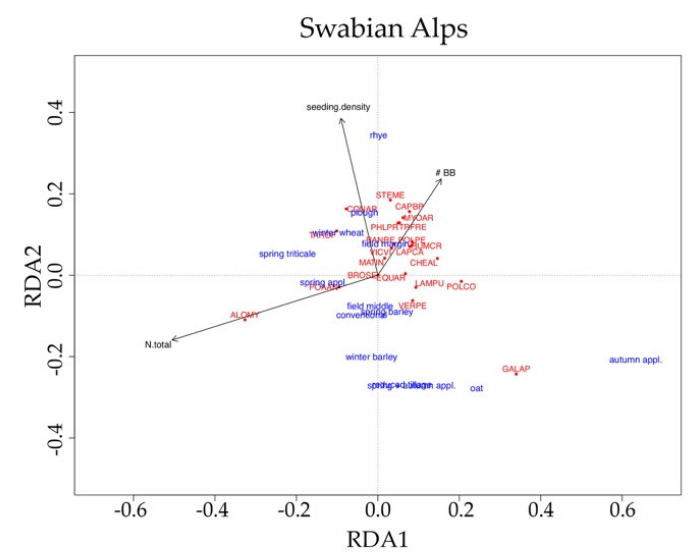

(b)

Figure 4. Ordination diagram of the partial redundancy analysis (RDA) from (a) the Gäu region and (b) the Swabian Alps containing (a) six and (b) eight significant explanatory variables. Only species with the highest fit on the first two axes are displayed. Eigenvalues for (a) the Gäu region are 0.083 for RDA1 and 0.058 for RDA2 with total inertia of 0.703 and 0.299 for all constrained axes. Eigenvalues for the (b) Swabian Alps are 0.057 for RDA1 and 0.045 for RDA2 with total inertia of 0.689 and 0.321 for all constrained axes. Abbreviation of weed species according to the EPPO Code.

\subsection{Endangered Weed Species (EWS)}

In the Swabian Alps, only two EWS, namely Bromus secalinus and Neslia paniculata, were found. Bromus secalinus was discovered in three conventional fields with a population size of around 10-30 plants, while Neslia paniculata occurred only once inside a conventional field. In the Gäu region, we found Bromus grossus and Bromus secalinus in relatively high numbers, so that we were able to analyze possible variables affecting the occurrence of these two species. Figure 5 displays the variables affecting the abundance of these two species. Both were found with significantly higher soil coverage at field margins and under the influence of combined spring and autumn herbicide applications. Bromus secalinus was mainly present in those fields, which were not sprayed with Atlantis 
( $0.3 \mathrm{~kg} \mathrm{ha}^{-1}$; a.i. iodosulfuron and mesosulfuron; Bayer Crop Science, Langenfeld, Germany) or Broadway (0.22 $\mathrm{kg} \mathrm{ha}^{-1}$; a.i. pyroxsulam and florasulam, Dow AgroSciences, Munich, Germany) in autumn and spring, respectively. The coverage of Bromus grossus was half as much as that of Bromus secalinus in both cases. A correlation test between the two species was significant $\left(R^{2}=0.572\right)$. Bromus secalinus displayed a significant reaction to soil type, with higher values at heavy soils with high clay content (lT and $\mathrm{tL}$ ) and decreasing values towards soils with a higher portion of silt (tU). Bromus grossus was mainly present in winter barley fields, although not significantly different from the other crop species. In addition, Bromus arvensis and Galium spurium were found at four field margins of conventional fields; Veronica triphyllos once at a conventional field margin; and Camelina alyssum and Ranunculus arvensis once and twice, respectively, restricted to organic fields. The number of individuals of these species was rarely higher than 5-20 plants.

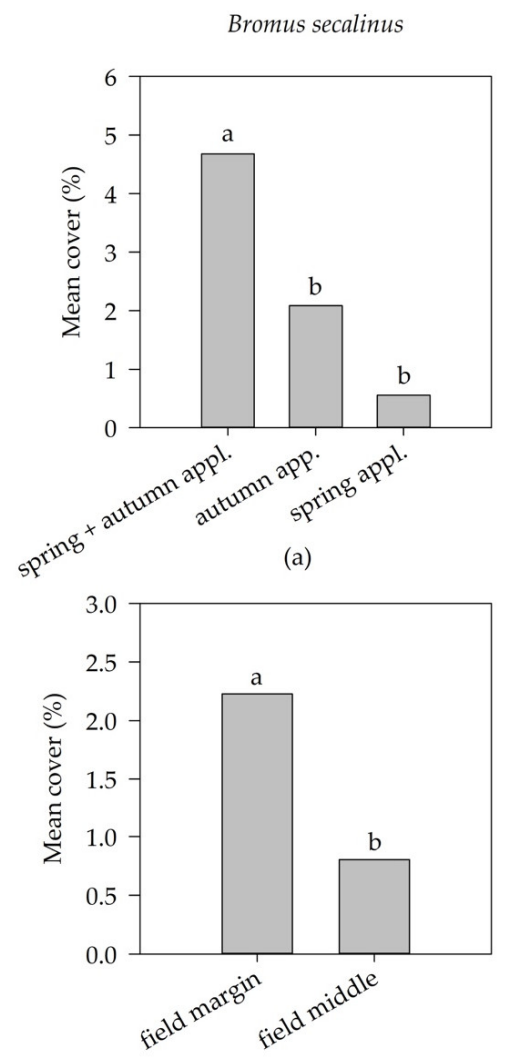

(c)

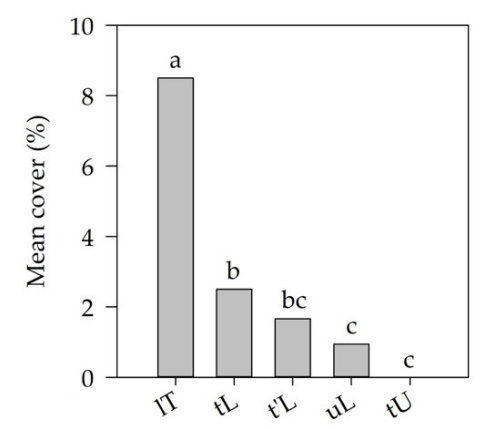

(e)

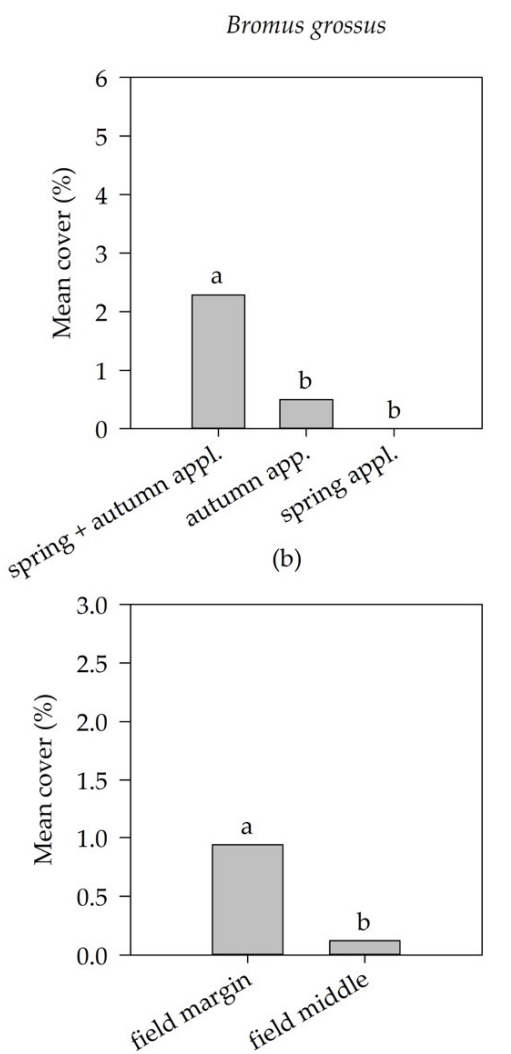

(d)

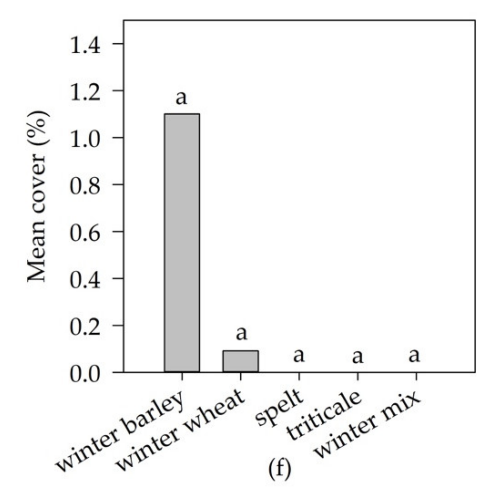

Figure 5. Factors influencing the mean cover (\%) of (a,c,e) Bromus secalinus and (b) Bromus grossus in the Gäu region. (a,b) Timing of herbicide application; (c,d) location in the field; (e) soil type (lT = loamy clay, $\mathrm{tL}=$ clayey loam, $\mathrm{t}^{\prime} \mathrm{L}=$ weakly clayey loam, $\mathrm{uL}=$ silty loam, $\mathrm{tU}=$ loamy silt); and (f) crop species. Means with different letters represent significant differences according to the Tukey HSD test $(p \leq 0.05)$. 


\section{Discussion}

Most of the EWS that were once present in the Gäu region and the Swabian Alps have either decreased in their numbers or even disappeared. Camelina alyssum and Bromus grossus in particular are supposed to be extinct in many regions of Germany. The two regions, Gäu and Swabian Alps, thus have a high responsibility to ensure their conservation and promotion. Bromus secalinus was the only rather frequent EWS in the Gäu region. As it is presumed to have descended from Bromus grossus [33], the identified factors influencing Bromus secalinus might also help to develop better conservation measures for Bromus grossus. The two Bromus species were positively affected by herbicide applications, which may be because of the fact that the applied herbicides in the respective locations are known to have a gap in effectiveness against Bromus species. Therefore, it might be possible to promote species conservation not only in organic farming [34], but even with the use of herbicides in conventional farming, at least for these particular species. In contrast, it was assumed that Bromus grossus was only able to survive in fields if it is reintroduced using uncleaned crop seeds from previous years [35]. However, the control of other, more competitive species needs also to be concerned, as this might interfere greatly with the success of facilitating endangered species. In particular, measures affecting a whole group of weeds, like the promotion of grassy weeds by conservation tillage [36], might not aid in conservation. To facilitate the propagation of EWS is of paramount importance, as their genetic variability is quite low [15] and needs to be increased, if necessary, even by reintroduction of new seeds [37].

As a result of the rapid disappearance of ever more weed species, the weed community is becoming less diverse and uniform across Germany. This uniform weed community consists of well adapted dominant species that cause high yield losses, such as Alopecurus myosuroides and Galium aparine [37]. These two species were also the most frequently found weeds in the present study and those displaying the highest soil coverage. Moreover, Alopecurus myosuroides, Galium aparine, Polygonum convolvulus, and Viola arvensis were associated with low soil disturbance and higher values of nitrogen. This is in line with other studies that found weed communities dominated by these species under intensive conventional farming $[38,39]$. With regard to climate change, weed communities will further evolve. EWS will become even more vulnerable to the new weather conditions [40] and difficult to control, and invasive weed species might spread into more agricultural fields [41]. This can shift the weed community further to one with a higher frequency of dominant species.

The main drivers found in this study that shaped the weed community were crop species, herbicide use, nitrogen fertilization, and tillage operations. Of these, crop species and timing of herbicides were the most influential in determining the weed composition. The influence of crops can be explained by the major differences in cultivation [42], ultimately leading to the typical weed communities of spring or autumn sown crops [43]. Other authors also found cropland type and surrounding habitats to be major drivers of weed composition [43]. Herbicide use leads to a massive selection pressure upon the weeds, resulting in very low densities of species per se or the evolution of herbicide resistance [23]. They are even potent enough to mask effects of tillage on weed community composition by leading to uniform weed communities [44]. In our study, timing of herbicides was also identified as a major factor, however, no consistent association between weeds and the herbicide application timing was found. This might be due to the wide range of available herbicides, each with its uniquely targeted weed species spectrum. Further studies should investigate the influence of herbicides and their active ingredients in more detail. Nitrogen fertilization was associated with higher abundance of Rumex species and Alopecurus myosuroides. The reaction of weed species to nitrogen content in the soil is common knowledge [45], however, there are still gaps in knowledge when it comes to its contribution to weed community composition. In regard to soil tillage, a regular disturbance of the soil promotes the emergence of more weed species and can also aid in conservation of EWS [26]. Apart from management factors, environmental and site conditions have a huge impact on the weed community composition [43,46,47], which were not available in detail for the present study. 
To increase the biodiversity in agricultural fields, the number of different weed species first of all needs to be raised in order to gain further increases in animal species. In this process, obviously most of the species will first be present in quite low numbers or coverages. Especially endangered species can contribute substantially to increasing agro-biodiversity, as they were once well integrated into the weed community. Their associated insect species might also benefit from the promotion of these weed species and will become more frequent.

Organic farming is promising in terms of biodiversity conservation [34], as no chemical plant protection agents are used and a more diverse crop rotation is practiced. These are two of the factors that we also found affecting the weed diversity positively. In terms of crop rotation, a higher diversity of crops seems to enhance weed diversity until a certain point $[46,48]$. In our study, this was highlighted by a medium number of crops in the crop rotation. Simple crop rotations promote those species that occur within the specific crop, thus resulting in one similar simple weed spectrum over the years. Very diverse rotations on the other hand make use of the weed suppressive effects exerted by particular timing of farming operations (e.g., tillage, sowing) and available weed control measures within each crop species. This diverse set of operations in the long-term might be able to diminish the soil seed bank in general, and species that have a low seed longevity in particular. Thus, a medium number of crops in the crop rotation might represent a maximum turning point for weed species diversity. Another important factor for higher diversity is the field margin, where fertilization, weed control, and sowing are often not as accurate as in the crop stand. Therefore, more light reaches the ground and gives many competition-weak weeds a chance to grow [49]. It would thus be suitable to start increasing weed diversity at the field margin to help in the conservation of species [50]. Moreover, field margins are associated with a higher diversity of fauna, including pollinators, beneficial insects, and farmland birds [51]. Field margins are a good start for conservation efforts and more diverse weed communities, but more area with suitable habitat conditions for a wide spectrum of weeds should be generated. Increasing weed diversity while simultaneously controlling problematic weeds and ensuring food security is a process in which every alteration needs to be carefully tested and evaluated. As a potential solution, there are already some techniques available to successively replace herbicide applications by mechanical treatments [52], or to manipulate the competitiveness of the crop by altering seeding patterns [53]. Furthermore, fertilizers can be placed quite accurately to the crop roots only [54], so that weeds need to cope with lower fertilizer levels, which in turn might lead to an increasing species richness if dominant, nitrogen-loving species decline [55].

In this context, field margin strips or entire fields farmed under nature conservation regulations and contracts can add a lot to increase biodiversity [56-58] and the goals set by the GSPC. This needs to be coordinated in order to gain a dense network of these programs and to provide the species with enough habitats linked by corridors, which ensures their future propagation and spread [59]. The disappearance of EWS and the low diversity of weed communities, especially in the Swabian Alps, emphasizes the need to make long-term contracts between farmers and nature conservation authorities. In fields, where the soil seed bank is highly depleted in terms of species diversity, it might be reasonable to reintroduce weed species by sowing [37], otherwise weed diversity is hard to restore. On the other hand, it might be problematic to introduce weed seeds from completely random areas, as they might not fit well into the regional weed community and might contain very dominant species. This approach must thus be executed with caution. Historical assessments of weed communities are available for many sites and should be taken into consideration for restoration of weed diversity. Moreover agri-environmental schemes and national strategies help to provide habitats for species in every type of farming. Furthermore, increasing the diversity in and around the field by intercropping, mixed cropping, and deliberately manipulating landscape structures can further assist in the recovery of agro-biodiversity [60]. To reach this goal, policy makers, nature conservation authorities, and farmers need to come (and stay) together to develop practical and sustainable solutions for both crop production and species conservation [4]. 
Author Contributions: Conceptualization, M.S., R.R., and S.O.; formal analysis, M.S.; investigation, R.R. and S.O.; writing-original draft preparation, M.S.; writing—review and editing, R.G.; supervision, R.G.

Funding: This research received no external funding.

Acknowledgments: We kindly thank the Landschaftserhaltungsverband Esslingen and Rottweil, the Regierungspräsidium Freiburg, and Esther Gerhards for access to former data sets, field maps, and introduction to the experimental areas. We also thank all the farmers that kindly allowed us to monitor their fields.

Conflicts of Interest: The authors declare no conflict of interest.

\section{References}

1. Convention on Biological Diversity-Safeguarding Life on Earth. Available online: https://www.cbd.int/ information/parties.shtml (accessed on 14 October 2018).

2. Power, M.E. Top-Down and Bottom-Up Forces in Food Webs: Do Plants Have Primacy. Ecology 1992, 73, 733-746. [CrossRef]

3. Scherber, C.; Eisenhauer, N.; Weisser, W.W.; Schmid, B.; Voigt, W.; Fischer, M.; Schulze, E.-D.; Roscher, C.; Weigelt, A.; Allan, E.; et al. Bottom-up effects of plant diversity on multitrophic interactions in a biodiversity experiment. Nature 2010, 468, 553-556. [CrossRef] [PubMed]

4. Holt, A.R.; Alix, A.; Thompson, A.; Maltby, L. Food production, ecosystem services and biodiversity: We can't have it all everywhere. Sci. Total Environ. 2016, 573, 1422-1429. [CrossRef] [PubMed]

5. Flynn, D.F.B.; Gogol-Prokurat, M.; Nogeire, T.; Molinari, N.; Richers, B.T.; Lin, B.B.; Simpson, N.; Mayfield, M.M.; DeClerck, F. Loss of functional diversity under land use intensification across multiple taxa. Ecol. Lett. 2009, 12, 22-33. [CrossRef] [PubMed]

6. Meyer, S.; Wesche, K.; Krause, B.; Leuschner, C. Dramatic losses of specialist arable plants in Central Germany since the 1950s /60s-A cross-regional analysis. Divers. Distrib. 2013, 19, 1175-1187. [CrossRef]

7. Hallmann, C.A.; Sorg, M.; Jongejans, E.; Siepel, H.; Hofland, N.; Schwan, H.; Stenmans, W.; Müller, A.; Sumser, H.; Hörren, T.; et al. More than 75 percent decline over 27 years in total flying insect biomass in protected areas. PLoS ONE 2017, 12, e0185809. [CrossRef] [PubMed]

8. Donald, P.F.; Green, R.E.; Heath, M.F. Agricultural intensification and the collapse of Europe's farmland bird populations. Proc. R. Soc. B Biol. Sci. 2001, 268, 25-29. [CrossRef] [PubMed]

9. Convention on Biological Diversity-Safeguarding Life on Earth. Available online: https://www.cbd.int/ agro/whatstheproblem.shtml (accessed on 14 October 2018).

10. Oerke, E.-C. Crop losses to pests. J. Agric. Sci. 2006, 144, 31-43. [CrossRef]

11. Blaix, C.; Moonen, A.C.; Dostatny, D.F.; Izquierdo, J.; Le Corff, J.; Morrison, J.; Von Redwitz, C.; Schumacher, M.; Westerman, P.R. Quantification of regulating ecosystem services provided by weeds in annual cropping systems using a systematic map approach. Weed Res. 2018, 58, 151-164. [CrossRef]

12. Marshall, E.J.P.; Brown, V.K.; Boatman, N.D.; Lutman, P.J.W.; Squire, G.R.; Ward, L.K. The role of weeds in supporting biological diversity within crop fields. Weed Res. 2003, 43, 77-89. [CrossRef]

13. Gerhards, R.; Dieterich, M.; Schumacher, M. Rückgang von Ackerunkräutern in Baden-Württemberg-Ein Vergleich von vegetationskundlichen Erhebungen in den Jahren 1948/49, 1975-1978 und 2011 im Raum Mehrstetten-Empfehlungen für Landwirtschaft und Naturschutz. Gesunde Pflanzen 2013, 65, 151-160. [CrossRef]

14. Atakan, E. Influence of weedy field margins on abundance patterns of the predatory bugs Orius spp. and their prey, the western flower thrips (Frankliniella occidentalis), on faba bean. Phytoparasitica 2010, 38, 313-325. [CrossRef]

15. Brütting, C.; Wesche, K.; Meyer, S.; Hensen, I. Genetic diversity of six arable plants in relation to their Red List status. Biodivers. Conserv. 2012, 21, 745-761. [CrossRef]

16. Gerowitt, B.; Bertke, E.; Hespelt, S.-K.; Tute, C. Towards multifunctional agriculture-weeds as ecological goods? Weed Res. 2003, 43, 227-235. [CrossRef]

17. Meyer, S.; Van Elsen, T.; Blümlein, B.; Kaerlein, M.; Metzger, J.; Gottwald, F.; Wehke, S.; Dieterich, M.; Wahmhoff, W.; Stock, R.; et al. Conserving agrobiodiversity through arable field sanctuaries. Natur und Landschaft 2014, 9, 434-441.

18. Firbank, L.G. Agrostemma githago L. (Lychnis githago (L.) Scop.). J. Ecol. 1988, 76, 1232-1246. [CrossRef] 
19. Van Elsen, T.; Hotze, C.; Meyer, S.; Gottwald, F.; Wehke, S. Empfehlungen für die Bewirtschaftung von Schutzäckern; University of Kassel: Kassel, Germany, 2009.

20. Meyer, S.; Van Elsen, T.; Gottwald, F.; Hotze, C.; Wehke, S. Monitoring-Konzept für die Entwicklung der Vegetation von Schutzäckern; University of Kassel: Kassel, Germany, 2010.

21. Waldhardt, R.; Simmering, D.; Albrecht, H. Floristic diversity at the habitat scale in agricultural landscapes of Central Europe-Summary, conclusions and perspectives. Agric. Ecosyst. Environ. 2003, 98, 79-85. [CrossRef]

22. Fried, G.; Petit, S.; Dessaint, F.; Reboud, X. Arable weed decline in Northern France: Crop edges as refugia for weed conservation? Biol. Conserv. 2009, 142, 238-243. [CrossRef]

23. Heap, I. Global perspective of herbicide-resistant weeds. Pest Manag. Sci. 2014, 70, 1306-1315. [CrossRef] [PubMed]

24. Albrecht, H. Suitability of arable weeds as indicator organisms to evaluate species conservation effects of management in agricultural ecosystems. Agric. Ecosyst. Environ. 2003, 98, 201-211. [CrossRef]

25. Schumacher, M.; Hahn, A.-K.; Gerhards, R. The Influence of Farming on Weed Flora in the Gäu Region of Southwestern Germany with an Emphasis on Rare Arable Weed Species; Julius-Kühn-Archiv: Braunschweig, Germany, 2018; Volume 458, pp. 30-34.

26. Torra, J.; Recasens, J.; Royo-Esnal, A. Seedling emergence response of rare arable plants to soil tillage varies by species. PLoS ONE 2018, 13, e0199425. [CrossRef] [PubMed]

27. Van Elsen, T. Ackerwildkraut-Gesellschaften herbizidfreier Ackerränder und des herbzidbehandelten Bestandesinneren im Vergleich. Tuexenia 1989, 9, 75-105.

28. Wilmanns, O. Ökologische Pflanzensoziologie: Eine Einführung in die Vegetation Mitteleuropas; 6. Auflage; Quelle \& Meyer: Wiesbaden, Germany, 1998; ISBN 978-3-8252-0269-9.

29. Van der Maarel, E. Transformation of cover-abundance values for appropriate numerical treatment Alternatives to the proposals by Podani. J. Veg. Sci. 2007, 18, 767-770. [CrossRef]

30. Legendre, P.; Gallagher, E.D. Ecologically meaningful transformations for ordination of species data. Oecologia 2001, 129, 271-280. [CrossRef] [PubMed]

31. Fox, J.; Monette, G. Generalized collinearity diagnostics. J. Am. Stat. Assoc. 1992, 87, 178-183. [CrossRef]

32. Lososová, Z.; Chytrý, M.; Cimalová, Š.; Kropáč, Z.; Otýpková, Z.; Pyšek, P.; Tichý, L. Weed vegetation of arable land in Central Europe: Gradients of diversity and species composition. J. Veg. Sci. 2004, 15, 415-422. [CrossRef]

33. Koch, M.A.; Meyer, N.; Engelhardt, M.; Thiv, M.; Bernhardt, K.-G.; Michling, F. Morphological and genetic variation of highly endangered Bromus species and the status of these Neolithic weeds in Central Europe. Plant Syst. Evol. 2016, 302, 515-525. [CrossRef]

34. Van Elsen, T. Species diversity as a task for organic agriculture in Europe. Agric. Ecosyst. Environ. 2000, 77, 101-109. [CrossRef]

35. Piqueray, J.; Gilliaux, V.; Gaillard, T.; Mahy, G.; Delescaille, L.-M. Uncleaned crop seed sowing as a tool to conserve Bromus grossus and restore species-rich arable-dependent plant communities. Conserv. Evid. 2018, 15, 26-31.

36. Peigné, J.; Ball, B.C.; Roger-Estrade, J.; David, C. Is conservation tillage suitable for organic farming? A review. Soil Use Manag. 2007, 23, 129-144. [CrossRef]

37. Lang, M.; Prestele, J.; Wiesinger, K.; Kollmann, J.; Albrecht, H. Reintroduction of rare arable plants: Seed production, soil seed banks, and dispersal 3 years after sowing: Reintroduction of rare arable plants. Restor. Ecol. 2018, 26, 170-178. [CrossRef]

38. Keller, M.; Böhringer, N.; Möhring, J.; Rueda-Ayala, V.; Gutjahr, C.; Gerhards, R. Long-term changes in weed occurrence, yield and use of herbicides in maize in south-western Germany, with implications for the determination of economic thresholds. Weed Res. 2014, 54, 457-466. [CrossRef]

39. Dessaint, F.; Chadoeuf, R. Barralis Diversity of weed communities of annual crops in côte-d'Or, France. Biotechnol. Agron. Soc. Environ. 2001, 5, 91-98.

40. Rühl, A.T.; Eckstein, R.L.; Otte, A.; Donath, T.W. Future challenge for endangered arable weed species facing global warming: Low temperature optima and narrow moisture requirements. Biol. Conserv. 2015, 182, 262-269. [CrossRef]

41. McDonald, A.; Riha, S.; DiTommaso, A.; DeGaetano, A. Climate change and the geography of weed damage: Analysis of U.S. maize systems suggests the potential for significant range transformations. Agric. Ecosyst. Environ. 2009, 130, 131-140. [CrossRef] 
42. Nowak, A.; Nowak, S.; Nobis, M.; Nobis, A. Crop type and altitude are the main drivers of species composition of arable weed vegetation in Tajikistan. Weed Res. 2015, 55, 525-536. [CrossRef]

43. Nagy, K.; Lengyel, A.; Kovács, A.; Türei, D.; Csergő, A.M.; Pinke, G. Weed species composition of small-scale farmlands bears a strong crop-related and environmental signature. Weed Res. 2018, 58, 46-56. [CrossRef]

44. Derksen, D.A. Impact of post-emergence herbicides on weed community diversity within conservation-tillage systems. Weed Res. 1995, 35, 311-320. [CrossRef]

45. Chadwigk, M.J. The response to variations in nitrogen level of some weed species of the Sudan. Weed Res. 1963, 3, 230-241. [CrossRef]

46. De Mol, F.; von Redwitz, C.; Gerowitt, B. Weed species composition of maize fields in Germany is influenced by site and crop sequence. Weed Res. 2015, 55, 574-585. [CrossRef]

47. Pinke, G.; Blazsek, K.; Magyar, L.; Nagy, K.; Karácsony, P.; Czúcz, B.; Botta-Dukát, Z. Weed species composition of conventional soyabean crops in Hungary is determined by environmental, cultural, weed management and site variables. Weed Res. 2016, 56, 470-481. [CrossRef]

48. Zarina, L.; Gerowitt, B.; Melander, B.; Salonen, J.; Krawczuk, R.; Verwijst, T. Crop diversification for weed management in organic arable cropping systems. Environ. Technol. Resour. Proc. Int. Sci. Pract. Conf. 2015, 2, 333. [CrossRef]

49. Kleijn, D.; van der Voort, L.A.C. Conservation headlands for rare arable weeds: The effects of fertilizer application and light penetration on plant growth. Biol. Conserv. 1997, 81, 57-67. [CrossRef]

50. Schumacher, W. Schutz und Erhaltung gefährdeter Ackerwildkräuter durch Integration von landwirtschaftlicher Nutzung und Naturschutz. Natur und Landschaft 1980, 55, 447-453.

51. Marshall, E.J.P.; Moonen, A.C. Field margins in northern Europe: Their functions and interactions with agriculture. Agric. Ecosyst. Environ. 2002, 89, 5-21. [CrossRef]

52. Kunz, C.; Weber, J.; Gerhards, R. Benefits of Precision Farming Technologies for Mechanical Weed Control in Soybean and Sugar Beet-Comparison of Precision Hoeing with Conventional Mechanical Weed Control. Agronomy 2015, 5, 130-142. [CrossRef]

53. Kristensen, L.; Olsen, J.; Weiner, J. Crop Density, Sowing Pattern, and Nitrogen Fertilization Effects on Weed Suppression and Yield in Spring Wheat. Weed Sci. 2008, 56, 97-102. [CrossRef]

54. Blackmer, A.M.; White, S.E. Using precision farming technologies to improve management of soil and fertilizer nitrogen. Aust. J. Agric. Res. 1998, 49, 555-564. [CrossRef]

55. Storkey, J.; Moss, S.R.; Cussans, J.W. Using Assembly Theory to Explain Changes in a Weed Flora in Response to Agricultural Intensification. Weed Sci. 2010, 58, 39-46. [CrossRef]

56. Denys, C.; Tscharntke, T. Plant-insect communities and predator-prey ratios in field margin strips, adjacent crop fields, and fallows. Oecologia 2002, 130, 315-324. [CrossRef] [PubMed]

57. Meek, B.; Loxton, D.; Sparks, T.; Pywell, R.; Pickett, H.; Nowakowski, M. The effect of arable field margin composition on invertebrate biodiversity. Biol. Conserv. 2002, 106, 259-271. [CrossRef]

58. Krompa, B.; Steinberger, K.-H. Grassy field margins and arthropod diversity: A case study on ground beetles and spiders in eastern Austria (Coleoptera: Carabidae; Arachnida: Aranei, Opiliones). Biot. Divers. Agroecosyst. 2012, 71-93.

59. Meyer, S.; Leuschner, C.; Van Elsen, T. Sanctuaries for the segetal vegetation in Germany-Inventory and new impulses by the project "Biodiversity in agricultural landscapes". J. Plant Diseases Protect. 2008, 21, 363-368.

60. Landis, D.A. Designing agricultural landscapes for biodiversity-based ecosystem services. Basic Appl. Ecol. 2017, 18, 1-12. [CrossRef]

(C) 2018 by the authors. Licensee MDPI, Basel, Switzerland. This article is an open access article distributed under the terms and conditions of the Creative Commons Attribution (CC BY) license (http://creativecommons.org/licenses/by/4.0/). 